\title{
Fluorki w kościach człowieka - wybrane zagadnienia
}

\author{
Fluorides in the human bones - selected issues
}

\author{
Mirona Palczewska-Komsa', Elżbieta Kalisińska², Anna Stogiera', Monika Szmidt \\ ${ }^{1}$ Katedra i Zakład Stomatologii Zachowawczej i Endodoncji Pomorskiego Uniwersytetu Medycznego w Szczecinie \\ al. Powstańców Wlkp. 72, 70-111 Szczecin \\ Kierownik: prof. dr hab. n. med. Jadwiga Buczkowska-Radlińska
}

${ }^{2}$ Katedra i Zakład Biologii i Parazytologii Medycznej Pomorskiego Uniwersytetu Medycznego w Szczecinie

al. Powstańców Wlkp. 72, 70-111 Szczecin

Kierownik: prof. dr hab. n. biol. Elżbieta Kalisińska

\begin{abstract}
Long-term intake of fluoride leads to skeletal fluorosis. The toxicity of fluoride, not only for the human body, but also the entire ecosystem makes it necessary to constantly monitor their content in the environment. Accordingly, there is a need to control the level of fluorides $\left(\mathrm{F}^{-}\right)$in humans, particularly in bone tissue, which reflects long-term accumulation of these compounds.

The aim of the study was to determine the concentration of fluoride in the human bones depending on biological factors and environmental conditions on the basis of the published literature.
\end{abstract}

Given the importance of bone tissue as the main reservoir of fluoride ions is an important issue to continue to monitor the concentration of $\mathrm{F}^{-}$in this tissue, particularly for people living in the polluted environment fluorine compounds. There are numerous works on concentrations of this element in human bones in world literature which proves the great interest in the subject. It should be underlined the need for further study of this issue for people living in different regions of Poland.

Keywords: fluorine compounds, bone tissue, humans, biomonitoring.

\section{STRESZCZENIE}

Długotrwała podaż fluoru prowadzi do fluorozy kostno-szkieletowej. Toksyczność fluorków $\left(\mathrm{F}^{-}\right)$, nie tylko dla organizmu człowieka, ale i całego ekosystemu, powoduje, że niezbędne jest stałe monitorowanie ich zawartości w środowisku. W związku z tym istnieje konieczność kontrolowania stężenia fluorków u ludzi, szczególnie w tkance kostnej, która odzwierciedla długofalową kumulację tych związków.

Celem pracy było określenie stężenia fluorków w kościach człowieka w zależności od czynników biologicznych i warunków środowiskowych na podstawie dostępnego piśmiennictwa.
Biorąc pod uwagę znaczenie tkanki kostnej jako głównego rezerwuaru jonów fluorkowych, istotnym problemem jest dalsze monitorowanie stężenia $\mathrm{F}^{-} \mathrm{w}$ tej tkance, szczególnie u osób bytujących w środowisku zanieczyszczonym związkami fluoru. Liczne są prace w piśmiennictwie światowym dotyczące stężenia tego pierwiastka w kościach ludzkich, co świadczy o dużym zainteresowaniu tą tematyką. Należy podkreślić potrzebę dalszych badań tego problemu w odniesieniu do osób zamieszkujących różne regiony Polski.

Słowa kluczowe: związki fluoru, tkanka kostna, ludzie, biomonitoring.

\section{WSTĘP}

Stała emisja fluorków do środowiska, zarówno naturalna, jak i antropogeniczna, stwarza niebezpieczeństwo intoksykacji człowieka tym pierwiastkiem. W związku z tym uzasadnione jest kontrolowanie stężenia fluoru u ludzi. Spośród różnych rodzajów materiałów biologicznych w ocenie ryzyka narażenia na fluorki $\left(\mathrm{F}^{-}\right)$duże znaczenie przypisuje się kościom, ponieważ ze względu na okresowy wzrost i ciągłą przebudowę są dobrym materiałem do badań długoterminowych kumulacji fluorków.

W pracy przedstawiono stężenia fluorków w kościach człowieka pod kątem wpływu zarówno czynników biologicznych, środowiskowych, jak i narażenia zawodowego na podstawie dostępnego piśmiennictwa naukowego.

\section{ŚREDNIE STĘŻENIE FLUORKÓW W KOŚCIACH CZŁOWIEKA}

Na wartość kumulacji fluorków w kościach człowieka wpływ ma wiele czynników, takich jak: wiek, płeć, przemiany metaboliczne, współtowarzyszące choroby kości i nerek, suplementacja fluorkami oraz długość i czas ekspozycji narażenia na $\mathrm{F}^{-}$. W tabeli 1 przedstawiono zakresy typowych stężeń fluorków opisanych w kościach ludzkich (osób zdrowych, niesuplementowanych fluorkami, żyjących na niezanieczyszczonych $\mathrm{F}^{-}$obszarach) $[1,2,3,4,5,6,7]$.

Największą wartość w zakresie typowych stężeń fluorków w kościach ludzkich podają Kaminsky i wsp. [5], a najmniejszą Suzuki [1]. Na szczególną uwagę zasługuje praca Tankersley i Wells [2], w której zostały przedstawione wartości stężenia 
TABELA 1. Zakresy i średnie stężenia fluorków (zwykle w $\mathrm{mg} \cdot \mathrm{kg}^{-1}$ ) w kościach ludzkich nieeksponowanych na fluorki

\begin{tabular}{|c|c|c|}
\hline Zakres, średnia & Rodzaj kości & Źródło \\
\hline $\begin{array}{l}\text { 0,0155-0,0254\% s.m. } \\
155-254 \text { s.m. }\end{array}$ & $\begin{array}{l}\text { różne kości } \\
\text { archeologiczne } \\
\text { (istota zbita) }\end{array}$ & $\begin{array}{l}\text { Tankersley } \\
\text { i Wells [2] }\end{array}$ \\
\hline $\begin{array}{l}500-1000 p \\
294-588 \text { s.m. }\end{array}$ & różne kości & Reddy [3] \\
\hline $\begin{array}{l}<396 \text { m.m. } \\
<566 \text { s.m. }\end{array}$ & różne kości & Vieira i wsp. [4] \\
\hline $\begin{array}{l}500-4000 p \\
294-2353 \text { s.m. }\end{array}$ & różne kości & $\begin{array}{l}\text { Kaminsky } \\
\text { i wsp. [5] }\end{array}$ \\
\hline $\begin{array}{l}\text { 0,042\% s.m. } \\
420 \text { s.m. }\end{array}$ & kość biodrowa & Franke [6] \\
\hline $\begin{array}{l}\text { 100-500 s.m. } \\
\text { 100-400 s.m. } \\
<115 \text { s.m. } \\
<110 \text { s.m. } \\
<105 \text { s.m. } \\
<107 \text { s.m. }\end{array}$ & $\begin{array}{l}\text { żebra } \\
\text { kość biodrowa } \\
\text { kość udowa } \\
\text { czaszka } \\
\text { kość ramienna } \\
\text { kości śródręcza }\end{array}$ & Suzuki [1] \\
\hline $\begin{array}{l}\text { 500-700 s.m. } \\
\text { 200-300 s.m. }\end{array}$ & $\begin{array}{l}\text { żebra, mostek, kręgi } \\
\text { kości długie }\end{array}$ & $\begin{array}{l}\text { Jackson } \\
\text { i Weidmann [7] }\end{array}$ \\
\hline
\end{tabular}

s.m. - sucha masa; p - popiół; m.m. - mokra masa

fluorków w ludzkich kościach pochodzących sprzed 10 tys. lat (holocen), odnalezionych w jednej z jaskiń z okolic Hawkins Ridge (Ohio, USA). Kości w jaskini izolowane były od czynników zewnętrznych, takich jak opady atmosferyczne, nasłonecznienie i wiatry. Zakres stężenia $\mathrm{F}^{-}$dla kości cechował się znacznie mniejszą rozpiętością w porównaniu do obecnie notowanych, bowiem nie przekraczał $260 \mathrm{mg} \cdot \mathrm{kg}^{-1}$.

W Polsce przeprowadzono analizę zawartości fluorków w czaszkach archeologicznych pochodzących z okolic Sandomierza, Złotej i Lublina, które wydobyto z ziemnych pochówków [8]. Kości starsze pod względem wieku archeologicznego (4000-1700 r. p.n.e.) charakteryzowały się większym stężeniem fluorków $\left(\sim 1000 \mathrm{mg} \cdot \mathrm{kg}^{-1}\right)$ w porównaniu do kości młodszych $\left(\sim 160 \mathrm{mg} \cdot \mathrm{kg}^{-1}\right)$, ponieważ fluorki są wbudowywane w apatyty głównie po śmierci osobniczej. Stopień intensywności tego procesu zależy od ilości fluorków w glebie, czasu ekspozycji i warunków środowiskowych [8]. Ponadto Noceń i wsp. [8], opierając się na pracach innych autorów, podają, że wraz ze wzrostem temperatury panującej w środowisku rośnie kumulacja fluorków w kościach.

Stwierdzono, że istnieją różnice między stężeniem fluorków w istocie zbitej i gąbczastej kości, przy czym większe powinowactwo fluorków notuje się w stosunku do kości gąbczastej $[9,10,11,12,13]$. W kości zbitej u osób zamieszkujących okolice Kuopio (Finlandia), nienarażonych na zwiększone oddziaływanie fluorków (0,02-0,32 $\mathrm{mg} \mathrm{F}^{-} \cdot \mathrm{L}^{-1} \mathrm{~W}$ wodzie pitnej), wartość maksymalna stężenia fluorków w kości biodrowej nie przekraczała $455 \mathrm{mg} \cdot \mathrm{kg}^{-1}$ suchej masy (s.m.), ale w kości gąbczastej była o 93\% większa i wynosiła $882 \mathrm{mg} \cdot \mathrm{kg}^{-1}$ s.m. [10]. Z kolei Arnala i wsp. [14] dokonali pomiaru stężenia fluorków w istocie gąbczastej kości biodrowej osób z okolic Kuopio w połowie lat 80. i uzyskali jeszcze mniejsze średnie wartości stężenia fluorków. U kobiet i mężczyzn średnie stężenia $\mathrm{F}^{-} \mathrm{w}$ kości wynosiły odpowiednio: 288 i $270 \mathrm{mg} \mathrm{F}^{-} \cdot \mathrm{kg}^{-1}$ s.m. Wartości te są porównywalne z maksymalnymi wartościami podanymi dla kości paleologicznych przez Tankersley i Wellsa [2].

Richards i wsp. [15] przeanalizowali stężenie fluorków w kości gąbczastej kręgów lędźwiowych, które pochodziły od Duńczyków bez objawów chorób układu kostnego. Wykazali, że średnie stężenie fluorków u kobiet wynosiło $1338 \mathrm{mg} \cdot \mathrm{kg}^{-1}$ w popiele kostnym ( $780 \mathrm{mg} \cdot \mathrm{kg}^{-1} \mathrm{~s} . \mathrm{m}$.), a u mężczyzn było nieco mniejsze i nie przekraczało $1190 \mathrm{mg} \cdot \mathrm{kg}^{-1} \mathrm{w}$ popiele kostnym ( $690 \mathrm{mg} \cdot \mathrm{kg}^{-1}$ s.m.).

Ishiguro i wsp. [16] porównali stężenie fluorków w okostnej, śródkostnej i kości zbitej żeber pochodzących od mieszkańców Nagoya (Japonia) w wieku 20-93 lat. Stwierdzili znaczne różnice w stopniu nagromadzenia fluorków w wymienionych częściach kości. Zakresy średniego stężenia fluorków (wyrażone w przeliczeniu na mokrą masę) można ułożyć w tych częściach w następujący szereg: okostna $\left(24-1400 \mathrm{mg} \cdot \mathrm{kg}^{-1}\right)>$ istota zbita $\left(100-750 \mathrm{mg} \cdot \mathrm{kg}^{-1}\right)>$ śródkostna $\left(100-600 \mathrm{mg} \cdot \mathrm{kg}^{-1}\right)$. Ponadto u osób 20-letnich żadna z tych wartości, po przeliczeniu na suchą masę, nie przekraczała $450 \mathrm{mg} \cdot \mathrm{kg}^{-1}$, co może być uznane za istotną i użyteczną informację w studiach porównawczych dotyczących stężenia fluorków w kościach młodych ludzi pochodzących z terenów nimi niezanieczyszczonych.

Także w obrębie różnych typów kości (bez ich strukturalnego podziału) zaznaczają się różnice w stężeniu fluorków. Ich koncentracje w kościach osób nieeksponowanych na $\mathrm{F}^{-}$obserwuje się, w kolejności od największej do najmniejszej wartości: w kręgach (>500 mg.kg-1 s.m.) > w żebrach (100-500 mg. $\mathrm{kg}^{-1}$ s.m.) > w grzebieniu i kości biodrowej (100-450 $\mathrm{mg} \cdot \mathrm{kg}^{-1} \mathrm{~s} . \mathrm{m}$.) $>$ w kościach długich (100-300 mg. $\mathrm{kg}^{-1} \mathrm{~s} . \mathrm{m}$.) > w pozostałych kościach (>120 mg.kg ${ }^{-1}$ s.m.) $[1,6,7,10,17]$.

Z przytoczonych analiz wynika, że wszelkie porównania stężeń fluorków w kościach powinny uwzględniać zarówno elementy strukturalne, jak i typ kości, jednak nie zawsze jest to możliwe.

\section{WIEK A STĘŻENIE FLUORKÓW W KOŚCIACH}

W wielu opracowaniach wykazano istnienie zależności między wiekiem a kumulacją fluorków w kościach człowieka [1, 15, $16,18,19,20]$. Najmniejsze koncentracje fluorków notowane są w kościach płodów i małych dzieci, przy czym u płodów badanych przed $1970 \mathrm{r}$. na ogół nie przekraczały one $30 \mathrm{mg} \cdot \mathrm{kg}^{-1}$ s.m. [18]. W późniejszym okresie, u niemowląt i małych dzieci pochodzących z terenów niezanieczyszczonych fluorkami, Hellström [21] stwierdziła w żebrach 5 noworodków stężenie fluorków wynoszące $77 \mathrm{mg} \cdot \mathrm{kg}^{-1} \mathrm{~s} . \mathrm{m}$., natomiast u dzieci $\mathrm{w}$ wieku 6 lat $(\mathrm{n}=12)$ koncentracja $\mathrm{F}^{-} \mathrm{w}$ analogicznym materiale kostnym była prawie 2 -krotnie większa ( 130 mg. $\mathrm{kg}^{-1} \mathrm{~s} . \mathrm{m}$.). Obserwacja ta jest zbieżna z rezultatami uzyskanymi przez Suzuki [1] dotyczącymi 6 dzieci w wieku do 9 lat. Suzuki [1] badał również stężenia fluorków wśród Japończyków z różnych grup wiekowych zamieszkujących tereny niezanieczyszczone fluorkami. U osób w wieku 20-39 lat stwierdził najmniejsze średnie stężenie fluorków w kości biodrowej, które u mężczyzn 
i kobiet z grupy wiekowej wynosiło odpowiednio: 365 i 222 $\mathrm{mg} \cdot \mathrm{kg}^{-1} \mathrm{~s}$.m. Największe stężenia $\mathrm{F}^{-}$odnotował u osób w wieku 60-79 lat, gdyż u mężczyzn i kobiet osiągnęły one wartości 520 i $418 \mathrm{mg} \cdot \mathrm{kg}^{-1}$ s.m. Jednocześnie Suzuki [1] zwrócił uwagę, że u ludzi w wieku 70-79 lat następuje spadek stężenia fluorków w badanych kościach w stosunku do osób w wieku 60-69 lat. Stężenie fluorków w kościach najstarszych pacjentów wynosiło u mężczyzn i kobiet odpowiednio: 511 i $378 \mathrm{mg} \cdot \mathrm{kg}^{-1} \mathrm{~s} . \mathrm{m}$. Prawdopodobnie zmniejszenie stężenia fluorków w kościach osób po 69. r.ż. miało związek z utratą mineralnej gęstości kości i masy kostnej, które u ludzi fizjologicznie następuje po 40. r.ż. Jak wynika z pracy Suzuki [1], średnie stężenie fluorków w kościach mężczyzn we wszystkich grupach wiekowych było istotnie większe $(\mathrm{p}<0,01)$ w porównaniu do kobiet w podobnym wieku. Mogło to mieć związek z odmiennością procesów przebiegających w kościach starzejących się mężczyzn i kobiet uwarunkowanych hormonalnie. Szacuje się, że wraz z wiekiem kobiety tracą średnio 35-50\%, a mężczyźni 23-33\% masy kostnej [22].

Na relacje między stężeniem fluorków w kościach a wiekiem ludzi zwrócili również uwagę Hać i wsp. [19]. Stwierdzili oni, że w żebrach młodych osób (17-30 lat) z rejonu Gdańska stężenie fluorków było wyraźnie mniejsze w porównaniu do osób w wieku 61-87 lat, ponieważ średnie stężenia fluorków wynosiły odpowiednio: $<500$ i $~ 900 \mathrm{mg} \cdot \mathrm{kg}^{-1} \mathrm{~s}$.m. Wartość współczynnika korelacji dla badanej przez Hać i wsp. [19] zależności między stężeniem fluorków w kościach a wiekiem mieszkańców Gdańska i okolic okazała się istotna statystycznie $(\mathrm{r}=0,52 ; \mathrm{p}<0,001)$.

Dodatnią i istotną korelację między stężeniem fluorków $\mathrm{w}$ istocie gąbczastej żeber człowieka a ich wiekiem odnotowali Ishiguro i wsp. [16], którzy ponadto wykazali, że istnieje istotnie statystyczna różnica między stężeniem tego pierwiastka w kościach kobiet i mężczyzn z Nagoya (Japonia) w wieku 55 lat ( $p<0,05)$. Z kolei Richards i wsp. [15] potwierdzili związek między koncentracją $\mathrm{F}^{-} \mathrm{w}$ istocie gąbczastej kręgów lędźwiowych człowieka a wiekiem mężczyzn $(\mathrm{r}=0,51 ; \mathrm{p}<0,01) \mathrm{i}$ kobiet $(\mathrm{r}=0,60 ; \mathrm{p}<0,001)$.

Bohatyrewicz [11] stwierdził zależność między stężeniem fluorków w kości udowej pochodzących od 51 pacjentek (w wieku 54-92 lat po alloplastyce kości udowej z powodu złamań) a ich wiekiem, przy czym materiał do badań pochodził głównie od mieszkanek Szczecina i jego okolic. Pozytywnie skorelowane wyniki uzyskał on zarówno między koncentracją fluorków w istocie zbitej a wiekiem $(r=0,71 ; p<0,0001)$, jak i między koncentracją fluorków w istocie gąbczastej a wiekiem ( $\mathrm{r}=0,78 ; \mathrm{p}<0,0001)$. W próbkach kostnych pozyskanych od pacjentek chorujących na osteoporozę, będących mieszkankami tego samego regionu Polski, Bohatyrewicz i wsp. [20] nie stwierdzili istotnej korelacji między stężeniem fluorków w różnych strukturach kości a wiekiem pacjentek, ale potwierdzili dodatnią korelację między ich koncentracją w całej kości a wiekiem badanych osób $(r=0,87 ; \mathrm{p}<0,001)$. W innych badaniach Bohatyrewicz [12] uznał, że zawartość fluorków w istocie zbitej i gąbczastej kości pacjentek ze zwyrodnieniem stawu biodrowego nie zależy od ich wieku.
Również Alhava i wsp. [10] określili związek między stężeniem fluorków w kościach a wiekiem kobiet i mężczyzn z dwóch różnych obszarów Finlandii. Najsilniejsze pozytywne korelacje ( $r>0,70 ; p<0,001)$ stwierdzili między stężeniem fluorków w kości, zarówno w istocie zbitej i gąbczastej, jak i całej kości u mężczyzn z Kuopio, z terenów zaopatrywanych we fluorkowaną wodę pitną. U człowieka około 99\% fluorków jest gromadzonych w kościach i innych zmineralizowanych tkankach, przy czym ilość $\mathrm{F}^{-}$zdeponowanych w tych tkankach zależy od wieku osobniczego.

\section{STĘŻENIE FLUORKÓW W KOŚCIACH W ZALEŻNOŚCI OD STOPNIA NARAŻENIA ŚRODOWISKOWEGO}

Przeprowadzono badania dotyczące stężenia fluorków w kościach osób pochodzących z rejonów, w których występują one naturalnie w dużych stężeniach w środowisku. Arnala i wsp. [14] przeanalizowali próbki kości pod względem zawartości w nich fluorków uzyskane od 40 mężczyzn i 17 kobiet zamieszkujących południowo-wschodnią Finlandię, tereny endemicznie bogate we fluorki (do 7,6 $\mathrm{mg} \mathrm{F}^{-} \cdot \mathrm{L}^{-1}$ w wodzie pitnej). Średnie stężenie fluorków w kościach biodrowych (istota gąbczasta) mężczyzn z tych terenów wynosiło $1665 \mathrm{mg} \cdot \mathrm{kg}^{-1}$ s.m., natomiast u kobiet było większe o 23\% i przekraczało $2050 \mathrm{mg} \cdot \mathrm{kg}^{-1} \mathrm{~s} . \mathrm{m}$. Gron i wsp. [23] badali próbki kości ludzi zamieszkujących Boston (USA). W jednej ze spopielonych próbek wykryli stężenie fluorków sięgające aż $7580 \mathrm{mg} \cdot \mathrm{kg}^{-1}$ ( $\sim 460 \mathrm{mg} \cdot \mathrm{kg}^{-1}$ s.m.). Okazało się, że próbka pochodziła z kości łokciowej osoby wywodzącej się z rejonu Indii o naturalnie dużej ilości fluorków w środowisku. U tego pacjenta została zdiagnozowana endemiczna fluoroza.

Inny, pojedynczy przypadek fluorozy szkieletowej, będącej wynikiem narażenia zawodowego, opisali Weidmann i wsp. [9]. Dotyczył on człowieka przez 18 lat narażonego na kontakt z pyłem zawierającym fluorki (3,88\% fluorków w skałach fosforowych). W jego kościach długich koncentracja fluorków wynosiła 1800-2900 mg. $\mathrm{kg}^{-1}$ s.m., ale w żebrach dochodziła do $5600 \mathrm{mg} \cdot \mathrm{kg}^{-1} \mathrm{~s} . \mathrm{m}$.

Według Reddy'ego [3] stężenie fluorków w zakresie $3500-5500 \mathrm{mg} \cdot \mathrm{kg}^{-1} \mathrm{~W}$ popiele kostnym (odpowiednio: 2060-3235 mg.kg-1 S.m.) może prowadzić do osteosklerozy, sztywności i bólu stawów, niewielkich zwapnień więzadeł, natomiast stężenia $>6000 \mathrm{mg} \mathrm{F}^{-} \cdot \mathrm{kg}^{-1} \mathrm{w}$ popiele kostnym (odpowiednio: >3530 $\mathrm{mg} \mathrm{F}^{-} \cdot \mathrm{kg}^{-1}$ s.m.) powodują szkieletową fluorozę, egzostozy i wyraźne zwapnienia więzadeł, które ograniczają ruchomość stawów.

He i wsp. [24] zbadali stężenie fluorków w kościach udowych 26 ludzkich płodów w wieku 6-8 miesięcy z dwóch regionów Chin. W popiele kostnym 16 płodów z prowincji Syczuan (w której duże koncentracje fluorków w środowisku pochodzą ze spalania węgla) stężenie fluorków wynosiło $130 \mathrm{mg} \cdot \mathrm{kg}^{-1}$ (76 mg.kg-1 s.m.), przy czym wszystkie płody wykazywały symptomy fluorozy szkliwa, a u 87\% dodatkowo stwierdzono fluorozę szkieletową. Natomiast w popiele kostnym 
płodów z Chengdu, obszaru niezanieczyszczonego fluorkami, stężenie tego pierwiastka było mniejsze aż o $117 \%$ i wynosiło 60,5 mg. $\mathrm{kg}^{-1}$ (35 mg. $\left.\mathrm{kg}^{-1} \mathrm{~s} . \mathrm{m}\right)$, a płody nie wykazywały objawów fluorozy. Ponadto, He i wsp. [24] odnotowali statystycznie istotną różnicę $(\mathrm{p}<0,05)$ między stężeniem fluorków w kościach płodów z wymienionych obszarów Chin. Kilka przypadków ciężkiej fluorozy przemysłowej stwierdzono u mieszkańców Saksonii (Niemcy), miejscowości leżącej nieopodal fabryki produkującej fluorowodór. Średnie koncentracje fluorków w kościach tych osób przekraczały $5000 \mathrm{mg} \cdot \mathrm{kg}^{-1}$ s.m. [6].

Wśród badań prowadzonych w Polsce na uwagę zasługuje praca Hać i wsp. [19], w której scharakteryzowano stężenie fluorków w żebrach ludzi (w wieku 17-87 lat) z terenu Gdańska i okolic, gdzie u ujścia Wisły zlokalizowane są zakłady fosforowe emitujące niegdyś znaczne ilości fluorków. Średnie stężenie związków fluoru w próbkach kości wynosiło $626 \mathrm{mg} \cdot \mathrm{kg}^{-1} \mathrm{~s} . \mathrm{m}$. i było 1,5-krotnie większe w porównaniu do stężenia fluorków w próbkach kości udowych (413 mg. $\mathrm{kg}^{-1}$ s.m.) pochodzących od mieszkańców Szczecina badanych w pracy Palczewskiej-Komsy i wsp. [25]. Należy dodać, że w Szczecinie i jego okolicach (Police) znajdują się zakłady chemiczne wykorzystujące w produkcji fluoroapatyty oraz elektrociepłownie i elektrownie emitujące $\mathrm{F}^{-}$, obecnie znacznie zmodernizowane w porównaniu do lat 80. XX w.

Obok fluorozy endemicznej i rozwijającej się na tle zmienionych antropogenicznie warunków, uwagę naukowców zwraca wpływ sztucznie fluorkowanej wody na stężenie fluorków w kościach. Wydaje się, że największe różnice obserwowane są między intensywnie rosnącymi organizmami (płodami i małymi dziećmi) pochodzącymi z terenów, gdzie woda nie była fluorkowana i obszarów, na których prowadzono jej sztuczną fluoryzację.

Adler [18], opierając się na wcześniejszych pracach innych autorów, stwierdził, że stężenia fluorków w kościach udowych 6-8-miesięcznych płodów ludzkich z Izraela zależą od stężenia fluorków w wodzie pitnej. W popiele kostnym płodów z Tel Awiwu (0,1 $\mathrm{mg} \mathrm{F}^{-} \cdot \mathrm{L}^{-1} \mathrm{w}$ wodzie pitnej) koncentracja fluorków wynosiła $41 \mathrm{mg} \cdot \mathrm{kg}^{-1}\left(24 \mathrm{mg} \cdot \mathrm{kg}^{-1} \mathrm{~s} . \mathrm{m}\right.$.), natomiast w kościach płodu z Jerozolimy (0,5 $\mathrm{mg} \mathrm{F}^{-} \cdot \mathrm{L}^{-1} \mathrm{w}$ wodzie pitnej) była o $85 \%$ większa i osiągnęła wartość $75 \mathrm{mg} \cdot \mathrm{kg}^{-1} \mathrm{w}$ popiele kostnym (44 mg.kg-1 s.m.).

W Szwecji również przeanalizowano stężenie fluorków w żebrach noworodków, uwzględniając stężenie w wodzie pitnej [21]. W suchej masie żeber noworodków pochodzących z obszaru nieskażonego fluorkami $\left(<0,8 \mathrm{mg} \mathrm{F}^{-} \cdot \mathrm{L}^{-1} \mathrm{~W}\right.$ wodzie pitnej) koncentracja fluorków wynosiła $77 \mathrm{mg} \cdot \mathrm{kg}^{-1}$ s.m. Natomiast u noworodków z obszaru, gdzie stężenie $\mathrm{F}^{-} \mathrm{w}$ wodzie pitnej wynosiło $>0,8 \mathrm{mg} \cdot \mathrm{L}^{-1}$, ich koncentracja w kościach była większa o 72\% (133 mg. $\mathrm{kg}^{-1}$ s.m.).

Analogiczne analizy przeprowadzone zostały także na próbkach kostnych uzyskanych od ludzi dorosłych. W populacji Brytyjczyków Jackson i Weidmann [7] zbadali oddziaływanie różnych stężeń fluorków znajdujących się w wodzie pitnej na ich koncentrację w istocie gąbczastej żeber. U osób z obszaru Leeds, gdzie wody nie fluorkowano i ich naturalny poziom był niewielki, w próbach kostnych tamtejszych mieszkańców zakres stężenia był mały (25-349 $\mathrm{mg} \mathrm{F}^{-} \cdot \mathrm{kg}^{-1}$ s.m.). Chociaż zakres stężenia fluorków w próbkach kostnych populacji z South Shields (0,8 $\mathrm{mg} \mathrm{F}^{-} \cdot \mathrm{L}^{-1} \mathrm{w}$ wodzie pitnej) był podobny (147-270 $\mathrm{mg} \cdot \mathrm{kg}^{-1} \mathrm{~s} . \mathrm{m}$.), to jednak jego dolna wartość była kilkukrotnie większa w porównaniu do analogicznej u osób z Leeds. Maksymalne stężenia fluorków odnotowano w kościach ludzi z West Haetlepool (16-574 mg. $\mathrm{kg}^{-1}$ s.m.), przy czym spożywali oni wodę zawierającą $1,9 \mathrm{mg} \mathrm{F}^{-} \cdot \mathrm{L}^{-1}[7]$.

Pod koniec lat 70. XX w. w Finlandii Alhava i wsp. [10] przeprowadzili porównania między zawartością fluorków w kościach biodrowych osób zamieszkujących dwa obszary o różnym stężeniu fluorków w wodzie pitnej. W miejscowości Kuopio prowadzono fluoryzację wody od lat 50. do lat 90. XX w. ( $\left.\sim 1 \mathrm{mg} \mathrm{F}^{-} \cdot \mathrm{L}^{-1}\right)$, ale w okolicach wody nie fluorkowano i zawierała ona do $0,32 \mathrm{mg} \mathrm{F}^{-} \cdot \mathrm{L}^{-1}$. Oprócz stężenia fluorków w całej kości zbadano je również oddzielnie w istocie zbitej i gąbczastej kości biodrowych. Największy zakres stężenia fluorków (804-2360 mg. $\mathrm{kg}^{-1}$ popiołu kostnego, co odpowiada 470-1390 mg.kg ${ }^{-1}$ s.m.) wykryto w istocie gąbczastej kości mężczyzn z Kuopio.

Analogiczne badania kilka lat później przeprowadzili Arnala i wsp. [14]. Średnie stężenie fluorków w istocie gąbczastej kości biodrowej mężczyzn z Kuopio (pijących sztucznie fluorkowaną wodę zawierającą $\sim 1 \mathrm{mg} \mathrm{F}^{-} \cdot \mathrm{L}^{-1}$ ) wynosiło $1220 \mathrm{mg} \cdot \mathrm{kg}^{-1}$ w popiele kostnym ( $720 \mathrm{mg} \cdot \mathrm{kg}^{-1} \mathrm{~s} . \mathrm{m}$.) i mieściło się w zakresie podanym dla mężczyzn z Kuopio [10]. Jednoznaczna interpretacja tych wyników jest trudna, gdyż w analizowanych grupach z różnych lat ujęto próbki kostne pochodzące od osób z szerokich przedziałów wiekowych (20-92 lata).

W porównaniu do przedstawionych danych znacznie większe wartości stężenia fluorków w kościach biodrowych (sięgające $1600 \mathrm{mg} \cdot \mathrm{kg}^{-1}$ s.m.) stwierdzono u osób z Grand Rapids (USA) spożywających fluorkowaną wodę o stężeniu $\mathrm{F}^{-}$zbliżonym do wody w Kuopio $\left(\sim 1,0 \mathrm{mg} \cdot \mathrm{L}^{-1}\right)$ [17]. Jednakże największą koncentrację fluorków w kościach biodrowych (4130 mg.kg-1 s.m.) wykryto u mieszkańców Lubbock (USA) wykorzystujących do celów konsumpcyjnych wodę z dużą zawartością fluorków (4 $\left.\mathrm{mg} \mathrm{F}^{-} \cdot \mathrm{L}^{-1}\right)$.

Wyniki badań prowadzonych przez Palczewską-Komsę i wsp. [25], dotyczące stężenia fluorków w kościach pacjentów pochodzących ze Szczecina (gdzie, jak podaje Lubkowska [26], koncentracja fluorków w wodzie wodociągowej wynosi $\sim 0,3 \mathrm{mg} \cdot \mathrm{L}^{-1}$ ), są zbliżone do wyników stężeń fluorków w kościach osób spożywających wodę zawierającą $<1,0 \mathrm{mg} \mathrm{F} \mathrm{F}^{-} \cdot \mathrm{L}^{-1}$ opisanych przez Jacksona i Weidmanna [7], Zipkina i wsp. [17] oraz Alhava i wsp. [10].

Oprócz fluorków znajdujących się we fluorkowanej lub niefluorkowanej wodzie pitnej oraz pożywieniu istotny wpływ na ich stężenie $\mathrm{w}$ kościach ludzi mają $\mathrm{F}^{-}$dostarczane do organizmu człowieka wraz z powietrzem. Zawierta i wsp. [13] zbadali stężenie fluorków w kościach udowych osób z Pomorza Zachodniego (Polska), a próbki kostne podzielili na dwie grupy ze względu na koncentrację antropogenicznego $\mathrm{F}^{-}$w powietrzu atmosferycznym. W grupie I i II znalazły się próbki uzyskane od osób zamieszkujących strefy, w których średnie stężenie fluorków w powietrzu wynosiło odpowiednio: 0,4 oraz 
$>1,6 \mu \mathrm{g} \cdot \mathrm{dm}^{-3}$. Odnotowano istotne różnice w stężeniu $\mathrm{F}^{-} \mathrm{w}$ próbkach kostnych pochodzących od osób z tych grup $(\mathrm{p}<0,05)$, przy czym ich koncentracja w próbkach grupy I (430 mg. $\mathrm{kg}^{-1} \mathrm{~s} . \mathrm{m}$.) była o 37\% mniejsza w porównaniu do próbek grupy II $\left(590 \mathrm{mg} \cdot \mathrm{kg}^{-1}\right)$. Przez wiele lat podkreślano korzyści płynące $\mathrm{z}$ endogennego działania fluorków. Działaniu egzogennemu przypisywano mniejsze znaczenie. Aktualne badania wskazują, że podstawowym mechanizmem przeciwpróchnicowego działania fluorków jest działanie miejscowe poprzez odkładanie się ich w szkliwie i zmniejszanie produkcji kwasów wytwarzanych przez bakterie kariogenne (próchnicze). W latach 90. XX w. w wielu krajach (w tym w Polsce) zaprzestano sztucznego fluorkowania wody. Ponadto obecnie na całym świecie obserwuje się tendencję do obniżania dopuszczalnego stężenia fluorków w wodzie oraz powietrzu.

\section{STĘŻENIE FLUORKÓW W KOŚCIACH A CHOROBY UKŁADU KOSTNO-STAWOWEGO}

W analizach koncentracji fluorków w tkance kostnej uwzględniane są także schorzenia układu kostno-stawowego. W niektórych z nich, np. osteoporosis i osteosclerosis, notuje się zarówno typowe, jak i zwiększone stężenia fluorków. U osób chorujących na różne schorzenia układu kostno-stawowego koncentracja $\mathrm{F}^{-}$może wahać się od $\sim 50$ do ponad $4100 \mathrm{mg} \cdot \mathrm{kg}^{-1} \mathrm{~s}$.m. Jedno z największych stężeń fluorków odnotowali Gron i wsp. [23] w próbce popiołu kostnego pobranego od pacjenta ze zdiagnozowaną osteoporozą (4129 $\mathrm{mg} \cdot \mathrm{kg}^{-1} \mathrm{~s} . \mathrm{m}$.), który pochodził z Bostonu (USA). Natomiast jedno z najmniejszych stężeń $\mathrm{F}^{-}$ wykryto w materiale kostnym badanym w pracy Palczewskiej-Komsy i wsp. [25]. Koncentrację, nieco ponad $54 \mathrm{mg} \mathrm{F}^{-} \cdot \mathrm{kg}^{-1}$ s.m., stwierdzono w próbce istoty zbitej kości udowej pacjenta ze zdiagnozowaną chorobą zwyrodnieniową stawów.

Bohatyrewicz [12] przeprowadził badania koncentracji fluorków u pacjentek szczecińskich szpitali, które poddane zostały allopastyce stawów biodrowych z powodu choroby zwyrodnieniowej stawów w latach 1994-1997. W grupie 32 pacjentek średnie stężenia $\mathrm{F}^{-} \mathrm{w}$ istocie zbitej i gąbczastej ich kości wynosiły odpowiednio: $\sim 40$ (czyli $760 \mathrm{mg} \cdot \mathrm{kg}^{-1} \mathrm{~s} . \mathrm{m}$.) i $\sim 48 \mathrm{mmol} \mathrm{F} \cdot \mathrm{kg}^{-1}$ (czyli $912 \mathrm{mg} \cdot \mathrm{kg}^{-1}$ s.m.), przy czym w kości gąbczastej stężenie było o $20 \%$ większe niż w kości zbitej. Ponadto autor ten stwierdził, że istnieje wyraźna korelacja między stężeniem fluorków w obu rodzajach kości $(r=0,65 ; \mathrm{p}<0,0001)$. W porównaniu do wyników Bohatyrewicza [12] w badaniach Palczewskiej-Komsy i wsp. [25] dotyczących 22 próbek istoty zbitej uzyskanych z główki kości udowej pacjentek, które również przeszły alloplastykę stawów biodrowych z takiego samego powodu, ale dekadę później (w 2009 r.), wartość ta okazała się o ponad $60 \%$ mniejsza.

Analizując dane dotyczące fluorków w kościach kobiet ( $n=42)$, które przebyły alloplastykę stawów biodrowych z powodu złamań kości udowej w latach 90. XX w., Bohatyrewicz [11] wykazał, że ich średnie stężenie w istocie zbitej $\left(\sim 42 \mathrm{mmol} \cdot \mathrm{kg}^{-1}\right.$, co odpowiada $794 \mathrm{mg} \cdot \mathrm{kg}^{-1} \mathrm{~s} . \mathrm{m}$.) było o ponad $40 \%$ mniejsze niż w istocie gąbczastej $\left(\sim 60 \mathrm{mmol} \mathrm{F}^{-} \cdot \mathrm{kg}^{-1}\right.$, co w przeliczeniu na s.m. wynosi $1140 \mathrm{mg} \cdot \mathrm{kg}^{-1}$ ). Wartości te są nieznacznie mniejsze od zawartych w publikacji Bohatyrewicza [12] oraz o 57\% mniejsze w porównaniu do wyników uzyskanych przez Palczewską-Komsę i wsp. [25].

U pacjentek ( $n=8)$ ze zdiagnozowaną osteosklerozą (objawiającą się zaburzeniami mineralizacji, bez utraty masy kostnej) na tle choroby zwyrodnieniowej stawów, które były hospitalizowane w szczecińskich szpitalach, stężenie fluorków w kości udowej wynosiło $818 \mathrm{mg} \cdot \mathrm{kg}^{-1}$ s.m. [27]. Wartość ta była o 79\% większa w porównaniu do wyników przedstawionych przez Palczewską-Komsę i wsp. [25], które dotyczyły 22 pacjentek ze zwyrodnieniem stawów biodrowych hospitalizowanych ponad dekadę później. Na zaobserwowane różnice mogło mieć wpływ zaprzestanie sztucznej fluoryzacji wody w Szczecinie w latach 90. XX w., a także modernizacja Zakładów Chemicznych w Policach zmierzająca do ograniczenia emisji fluorków do środowiska, zapoczątkowana w połowie lat 90. XX w.

Koncentracja fluorków w kościach pacjentek z rozpoznaną osteoporozą (inaczej zrzeszotnienie kości polegające na utracie masy kostnej wraz ze spadkiem gęstości mineralnej, ale bez zaburzenia mineralizacji kości) była badana przez Bohatyrewicza i wsp. [20], którzy stwierdzili, że w części zbitej i gąbczastej kości udowej pacjentek z północno-zachodniej Polski fluorki występują w zróżnicowanych stężeniach (odpowiednio: 773 i $1123 \mathrm{mg} \cdot \mathrm{kg}^{-1}$ s.m.).

Wpływ fluorków na zmiany ich koncentracji w osteoporozie badano także w USA, przy czym należy zaznaczyć, że na zdecydowanej większości terytorium tego kraju prowadzona jest sztuczna fluoryzacja wody od kilkudziesięciu lat [28]. Duże wartości stężenia fluorków w kościach 16 pacjentów z Bostonu chorujących na zrzeszotnienie kości odnotowali Gron i wsp. [23]. Zakres stężenia $\mathrm{F}^{-} \mathrm{w}$ popiele $\mathrm{z}$ kości biodrowej wynosił u nich 541-7019 $\mathrm{mg} \cdot \mathrm{kg}^{-1}$ (co w przybliżeniu odpowiada 320-4130 mg.kg-1 s.m.) i znacznie odbiegał od zakresu stężenia fluorków w kościach 7 osób ze stwierdzoną osteoporozą, które objęto analizą w niniejszej rozprawie (54-1489 mg. $\mathrm{kg}^{-1} \mathrm{~s} . \mathrm{m}$.). Do tak dużej rozbieżności między przytoczonymi powyżej zakresami stężenia $\mathrm{F}^{-}$najprawdopodobniej przyczyniło się sztuczne fluorkowanie wody pitnej w USA.

Związki fluoru wykorzystywano w przeszłości do leczenia osteoporozy. Zbadano wpływ przyjmowania tych preparatów w leczeniu zrzeszotnienia kości na stężenie $\mathrm{F}^{-}$. Gron i wsp. [23] odnotowali istotną statystyczne różnicę $(\mathrm{p}<0,01)$ w stężeniu $\mathrm{F}^{-}$w kościach biodrowych pacjentów leczonych przez 12 miesięcy dużymi (nie podano dokładnych wartości) dawkami preparatów fluorkowych i osób ich nieprzyjmujących. Odpowiednie średnie wartości koncentracji $\mathrm{F}^{-} \mathrm{w}$ ich kościach wynosiły 2100 i $511 \mathrm{mg} \cdot \mathrm{kg}^{-1} \mathrm{~s} . \mathrm{m}$.

Patel [29] w terapii osteoporozy zastosował niewielkie, wolno uwalniające się dawki fluorku sodu, NaF (25 mg NaF 2 razy na dobę w 4 cyklach przez 14 miesięcy, po 12 miesiącach leczenia następowała 2-miesięczna przerwa) z ciągłym przyjmowaniem cytrynianu wapnia (400 mg 2 razy na dobę). U pacjentów poddanych takiemu leczeniu zaobserwowano wzrost mineralnej gęstości kości (BMD) we wszystkich miejscach szkieletu (w tym w szyjce kości udowej) w porównaniu 
do grupy otrzymującej placebo. Ponadto u 85\% pacjentów przyjmujących NaF nie zaobserwowano nowych złamań kręgów w porównaniu do $57 \%$ zanotowanych u pacjentów z grupy przyjmującej placebo $(\mathrm{p}<0,001)$. Bovin i wsp. [30] przeprowadzili badania dotyczące stężenia fluorków w kościach pacjentek z osteoporozą z Lyonu (Francja) przyjmujących NaF w schemacie podanym przez Patela [29]. Należy zaznaczyć że u części z nich dodatkowo stwierdzono defekt kalcyfikacji w kościach. U pacjentek bez defektu kalcyfikacji zanotowano zwiększenie ilości fluorków w kości o 140\%, ale u pacjentek z tym defektem koncentracja fluorków w kościach zwiększyła się o ponad 400\%. Rezultat ten okazał się zbieżny ze zwiększeniem stężenia fluorków w kościach pacjentek z Bostonu po leczeniu NaF [23].

Przeprowadzona przez Vestergaarda i wsp. [31] analiza dotyczącą wpływu NaF na mineralną gęstość kości wykazała, że leczenie fluorkami zwiększa BMD kręgosłupa i biodra, w zależności od czasu trwania leczenia. Ponadto w pracy tej w analizie podgrup pacjentów przyjmujących dawki fluorku ( $\geq 20 \mathrm{mg}$ /dzień) odnotowano obniżenie ryzyka złamań kości. Jednak, jak podaje Bohatyrewicz [12], stosowanie fluorków w leczeniu osteoporozy ograniczone jest wieloma czynnikami, do których należą m.in.: przewlekła niewydolność nerek, choroba wrzodowa, osteomalacja oraz rozmaite skutki uboczne (bóle kości, dolegliwości żołądkowo-jelitowe). Ponadto preparaty fluorkowe charakteryzuje tzw. wąskie okno terapeutyczne, gdyż łatwo może dojść do ich przedawkowania. Zbyt duże dawki fluorków prowadzą do nieregularnej i opóźnionej mineralizacji kości, w wyniku czego kości są bardziej podatne na złamania (mają większy stopień kompresji, ale mniejsze napięcie w porównaniu do zdrowych kości) oraz wywierają toksyczny wpływ na osteoblasty $[32,33]$. W związku z tym obecnie preparaty zawierające fluorki nie są już stosowane w leczeniu osteoporozy.

\section{PODSUMOWANIE}

Stężenie fluorków w kościach człowieka zależy od wielu czynników, zarówno biologicznych, jak i środowiskowych, w tym narażenia zawodowego. U ludzi zamieszkujących tereny niezanieczyszczone typowe średnie stężenie fluorków w kościach (odzwierciedlające tło geochemiczne) nie przekraczają $550 \mathrm{mg} \cdot \mathrm{kg}^{-1} \mathrm{~s}$.m. Porównania różnych danych dotyczących stężenia fluorków w kościach ludzi są utrudnione, ponieważ próbki analizowanego materiału kostnego pochodzą nie tylko z różnych typów kości, ale i z różnych ich części (np. kości zbitej, gąbczastej, okostnej lub śródkostnej), a ponadto uzyskiwane są od ludzi reprezentujących różne grupy wiekowe i zamieszkujących rozmaite środowiska.

Na podstawie przeanalizowanego piśmiennictwa stwierdzono, że poziom stężenia fluorków w kościach w znacznym stopniu zależy od czasu ekspozycji i dawki w miejscach narażenia na ten pospolity w środowisku pierwiastek, który do organizmu człowieka dostaje się wraz ze spożywaną wodą, pokarmem i wdychanym powietrzem. Z kolei ilość związków fluoru w środowisku może być uwarunkowana czynnikami naturalnymi (obecność minerałów, pyłów i gazów wulkanicznych oraz morskiej bryzy bogatych w jony $\mathrm{F}^{-}$) i/lub antropogenicznymi (przemysł emitujący fluorki). Ponadto u osób chorujących na różne schorzenia układu kostno-stawowego koncentracja $\mathrm{F}^{-}$może wahać się od $\sim 50$ do ponad $4100 \mathrm{mg} \cdot \mathrm{kg}^{-1}$ s.m. Należy również dodać, że czynniki biologiczne, w tym uwarunkowanie genetyczne, jak również wrażliwość i aktywność metaboliczna kości, oraz środowiskowe mogą się kumulować, co zwiększa prawdopodobieństwo wzrostu koncentracji $\mathrm{F}^{-}$ w tkance kostnej.

Biorąc pod uwagę znaczenie tkanki kostnej jako głównego rezerwuaru jonów fluorkowych, istotnym problemem jest dalsze monitorowanie stężenia $\mathrm{F}^{-} \mathrm{w}$ tej tkance, szczególnie u osób bytujących w środowisku zanieczyszczonym związkami fluoru. Liczne są prace w piśmiennictwie światowym dotyczące stężenia tego pierwiastka w kościach ludzkich. Dynamiczne zainteresowanie tematyką oznaczania fluorków w materiale biologicznym, w tym w kościach, przekłada się na mnogość publikacji naukowych z tego zakresu. Niniejsza praca jest jedynie próbą zasygnalizowania najważniejszych aspektów tego zagadnienia.

\section{PIŚMIENNICTWO}

1. Suzuki Y. The normal levels of fluorine in the bone tissue of Japanese subjects. Tohoku J Exp Med 1979;129:327-36.

2. Tankersley KB, Wells DH. Further evaluation of fluoride dating by ion selective electrode analysis. North Am Archeol 2011;32:247-65.

3. Reddy DR. Neurology of endemic skeletal fluorosis. Neurol India 2009;57:7-12

4. Vieira AP, Mousny M, Maia R, Hancock R, Everett ET, Grynpas MD. Assesment of teeth as biomarkers for skeletal fluoride exposure. Osteoporosis Int 2005;16:1576-82.

5. Kaminsky LS, Mahoney MC, Leach J, Melius J, Miller MJ. Fluoride: benefits and risks of exposure. Crit Rev Oral Biol Med 1990;1:261-81.

6. Franke J. Fluoride and ash content of bone in various stages of human fluorosis. Fluoride 1989;22:195-203.

7. Jackson D, Weidmann SM. Fluorine in human bone related to age and the water supply of different regions. J Pathol Bacteriol 1958;76:451-9.

8. Noceń I, Chlubek D, Żyluk B, Machoy Z, Rzeuski R, Samujło D. Analiza stosunków ilościowych magnezu w odniesieniu do zawartości fluorków, cynku, manganu i żelaza w kościach czaszek ludzkich w materiale archeologicznym. Biul Magnezol 1994;4:156-8.

9. Weidmann SM, Weatherell JA, Jackson D. The effect of fluoride on bone. Proc Nutr Soc Engl Scot 1963;22:105-10.

10. Alhava EM, Olkkonen H, Kauranen P, Kari T. The effect of drinking water fluoridation on the fluoride content, strenght and mineral density of human bone. Acta Orthop Scand 1980;51:413-20.

11. Bohatyrewicz A. Bone fluoride in proximal femur fractures. Fluoride 2001;34:227-35.

12. Bohatyrewicz A. Wpływ fluorków na metabolizm i właściwości mechaniczne tkanki kostnej na podstawie obserwacji klinicznych i badań doświadczalnych przeprowadzonych na szczurach. Ann Acad Med Stetin 2002; Suppl 73:8-85.

13. Zawierta J, Chlubek D, Dąbkowska E, Bohatyrewicz A, Wieczorek P, Walat $\mathrm{S}$, et al. Comparison of fluoride concentration in bones of humans and animals inhabiting the region of Western Pomerania and exposed to emissions of fluorine compounds from industrial sources. Environ Sci (Tokyo) 2002;9:283-8.

14. Arnala I, Alhava EM, Kauranen P. Effects of fluoride bone in Finland. Histomorphometry of cadaver bone from low and high fluoride areas. Acta Orthop Scand 1985;56:161-6. 
15. Richards A, Mosekilde L, Sogaard CH. Normal age-related changes in fluoride content of vertebral trabecular bone - relation to bone quality. Bone 1994;15:21-6.

16. Ishiguro K, Nagasaki H, Tsuboi S, Narita N, Kato K, Li J, et al. Distribution of fluoride in cortical bone of human rib. Calcif Tissue Int 1993;52:278-82.

17. Zipkin I, McClure FJ, Leone NC, Lee WA. Fluoride deposition in human bones after prolonged ingestion of fluoride in drinking water. Public Health Rep 1958;73:732-40.

18. Adler P. Fluorides and human health. Geneva: World Health Organization; 1970.

19. Hać E, Czarnowski W, Gos T, Krechniak J. Lead and fluoride content in human bone and hair in the Gdańsk region. Sci Total Environ 1997;206:249-54.

20. Bohatyrewicz A, Ogoński T, Dąbkowska E, Machoy Z. Skład mineralny tkanki kostnej blaszkowatej i zbitej u pacjentek ze złamaniem szyjki kości udowej na tle osteoporozy. In: Ogoński T, Samujło D, Machoy Z, editors. Fluor i biopierwiastki w biologii i medycynie. VIII Sympozjum Fluorowe; 1998 Apr 23-24; Szczecin. p. 70-4.

21. Hellström I. Studies on fluoride distribution in infants and small children. Scand J Dent Res 1976;84:119-36

22. Michajlik A, Ramotowski W. Anatomia i fizjologia człowieka. Warszawa: PZWL; 2009

23. Gron P, McCann HG, Bernstein D. Effect of fluoride on human osteoporotic bone mineral. J Bone Joint Surg Am 1966;48:892-8.

24. He H, Cheng Z, Liu W. Effects of fluorine on human fetus. Fluoride 2008;41:321-6.
25. Palczewska-Komsa M, Kalisińska E, Kosik-Bogacka I, Łanocha-Arendarczyk N, Budis H, Sokołowski S, et al. Fluoride in bones of patients after arthroplasty. Fluoride 2015;48(2):93-104.

26. Lubkowska A. Assessment of the safety of drinking water in the West-Pomeranian Voivodeship, Poland. FEB 2009;18:1086-9.

27. Dąbkowska E, Bohatyrewicz A, Wieczorek P, Rzeuski R, Mikołajek W, Noceń I, et al. Ocena zawartości fluoru i wapnia w kościach z osteosklerozą. In: Ogoński T, Samujło D, Machoy Z, editors. Fluor i biopierwiastki w biologii i medycynie. VIII Sympozjum Fluorowe; 1998 Apr 23-24; Szczecin; p. 75-8.

28. Lennon MA. One in a million: the first community trial of water fluoridation. Bull World Health Organ 2006;84:759-60.

29. Patel S. Current and potential future drug treatments for osteoporosis. Ann Rheum Dis 1996;55:700-14.

30. Bovin G, Duriez J, Chapuy MC, Flautre B, Hardouin P, Meunier PJ. Relationship between bone fluoride content and histological evidence of calcification defects in osteoporotic women treated long term with sodium fluoride. Osteoporosis Int 1993;3:204-8.

31. Vestergaard P, Jorgensen NR, Schwarz P, Mosekilde L. Effects of treatment with fluoride on bone mineral density and fracture risk - a meta-analysis. Osteoporos Int 2008;19:257-68.

32. Pitt P, Berry H. Fluoride treatment in osteoporosis. Postgrad Med J 1991; 67:323-6.

33. Mutschler E, Geisslinger G, Kroemer HK, Ruth P, Schafer-Korting M. Farmakologia i toksykologia. 2nd ed. Wrocław: Wyd MedPharm Polska; 2010. 